\title{
Pelatihan Penyusunan Kurikulum Pendidikan Agama Kristen Remaja di HKBP Jatisampurna Bekasi
}

\author{
Desi Sianipar ${ }^{1}$, Yunardi Kristian Zega ${ }^{2}$, Luterius $\mathrm{Nehe}^{3}$, Kristiantoro ${ }^{4}$ \\ $1,2,3,4$ Universitas Kristen Indonesia, Jakarta, Indonesia \\ desi.sianipar@uki.ac.id; yunardichristian@gmail.com; luteriusnehe@gmail.com; \\ lyhankarche18@gmail.com
}

\begin{abstract}
Abstrak
Pendidikan dan pengajaran Kristen di gereja harus dipersiapkan dengan baik. Salah satu yang harus dipersiapkan gereja adalah dapat menyusun kurikulum pendidikan agama Kristen. Kurikulum pendidikan agama Kristen harus disusun dengan sebaik mungkin, sehingga dapat memenuhi setiap kebutuhan yang diperlukan jemaat untuk menunjang pertumbuhan kerohanian mereka, sehingga jemaat dapat bertumbuh semakin dewasa sesuai dengan ajaran yang Alkitabiah. Dengan demikian, menyusun kurikulum pendidikan agama Kristen di gereja sangatlah penting, khususnya membuat kurikulum bagi kaum remaja yang adalah generasi dari penerus gereja. Oleh karena itu, kegiatan PkM ini dirancang untuk membantu para pembina remaja agar dapat meningkatkan kemampuan dalam menyusun kurikulum pendidikan agama Kristen yang sesuai dengan kebutuhan para remaja masa kini. Hasil yang diperoleh dari kegiatan ini adalah menghasilkan para pembina remaja yang dapat menyusun kurikulum pendidikan agama Kristen bagi remaja.
\end{abstract}

Kata kunci: Pelatihan, Kurikulum PAK, dan Remaja.

\begin{abstract}
Christian education and teaching in the church must be well prepared. One of the things that must be prepared by the church is to be able to arrange a Christian religious education curriculum. The curriculum of Christian religious education must be arranged as well as possible, so that it can meet every need needed by the congregation to support their spiritual growth, so that the church can grow more mature according to biblical teachings. Thus, developing a Christian religious education curriculum in the church is very important, especially making a curriculum for young people who are the generation of church successors. Therefore, this PkM activity is designed to help youth coaches to improve their ability to compile a Christian religious education curriculum that suits the needs of today's youth. The results obtained from this activity are to produce adolescent coaches who can compile a Christian religious education curriculum for adolescents.
\end{abstract}

Keywords: Training, PAK Curriculum, and Youth. 


\section{PENDAHULUAN}

Pendidikan Agama Kristen adalah pelayanan pendidikan yang memberikan pondasi pengajaran iman Kristen kepada setiap peserta didik baik melalui keluarga, gereja, maupun sekolah. Menurut E.G. Homrighousen bahwa, Pendidikan Agama Kristen yaitu usaha sadar yang dilakukan oleh gereja untuk mendidik peserta didiknya dalam rangka agar mereka dapat mewarisi iman Kristen dengan segala kebenarannya, sebagaimana yang dinyatakan dalam Alkitab mereka harus memiliki hidup yang harmonis sesuai dengan iman Kristen dan menjadi anggota gereja dewasa yang dapat menyadari, menyakini, dan menyatakan imannya dalam kehidupan praktik sehari-hari (Budiyana, 2011, 6). Kemudian Robert R. Boelhke memberikan rumusan Pendidikan Agama Kristen sebagai usaha yang harus dilakukan gereja dengan sengaja untuk menolong semua jemaatnya dalam menjawab penyertaan Allah dalam Yesus Kristus dan Alkitab. Kehidupan gereja juga harus di bawah pimpinan Roh Kudus dalam memperlengkapi jemaat untuk melayani baik di tengah gereja, masyarakat luas, maupun alam sekitar (Budiyana, 2011, 6). Oleh karena itu, Pendidikan Agama Kristen harus dilakukan dengan sadar dan terencana, supaya setiap jemaat dapat mewarisi iman Kristen yang sesuai dengan kebenaran Alkitab, khususnya bagi generasi penerus gereja yaitu kaum remaja. Dengan memberikan Pendidikan Agama Kristen secara sadar dan terencana kepada kaum remaja, diharapkan kaum remaja dapat menjadi penerus gereja yang memiliki pertumbuhan kerohanian yang baik.

Menurut Piaget, secara psikologis remaja adalah suatu usia di mana individu menjadi terintegrasi ke dalam masyarakat dewasa, suatu usia di mana anak tidak merasa bahwa dirinya berada di bawah tingkat orang yang lebih tua melainkan merasa sama dan sejajar. Remaja artinya "tumbuh atau tumbuh untuk mencapai kematangan" yang mencakup kematangan mental, emosional, sosial, dan fisik. Remaja sebenarnya sudah tidak termasuk golongan anak-anak, tetapi belum juga dapat diterima secara penuh untuk masuk ke golongan orang dewasa. Jadi, remaja ada di antara anak dan orang dewasa. Dengan demikian, remaja sering kali dikenal dengan fase mencari jati diri. Remaja masih belum mampu menguasai dan memfungsikan secara maksimal fungsi fisik maupun psikisnya. Namun, perlu diketahui bahwa fase remaja merupakan fase perkembangan yang berada pada masa amat potensial, baik dari aspek kognitif, emosi, maupun fisiknya (Ali, 2010, 9-10). Oleh karena itu, sangat penting bagi para pendidik remaja dapat menyusun kurikulum PAK remaja yang sesuai dengan kebutuhan yang diperlukan remaja untuk menunjang pertumbuhan kerohanian mereka.

Kurikulum PAK adalah pengalaman pelajar di bawah bimbingan. Di mana kurikulum berorientasi pada Alkitab sebagai kegiatan-kegiatan yang dibimbing dan dilaksanakan oleh para pendidik Kristen agar dapat membawa peserta didik lebih dekat kepada kedewasaan dalam Kristus. Kegiatan- 
kegiatan ini melibatkan interaksi dari para pendidik dengan peserta didik yang berdasarkan Firman Allah (Lebar, 2006, 307). Jadi, kurikulum PAK merupakan kegiatankegiatan yang harus disusun sebaik mungkin, secara teratur, dan disiplin oleh setiap pendidik, sehingga dapat mengarahkan remaja untuk memiliki kehidupan dewasa yang sesuai dengan ajaran Firman Allah.

Di dalam menyusun kurikulum PAK remaja tentu tidak sembarangan dan harus disusun oleh para pendidik yang benar-benar memiliki keahlian untuk hal itu. Pendidik tersebut harus dapat menguasai dan mengetahui kebutuhan apa yang cocok dan tepat untuk menunjang pertumbuhan dan perkembangan remaja yang mereka didik. Jika pendidik tidak dapat mengetahui setiap permasalahan remaja dan hanya menyusun kurikulum hanya berdasarkan kemauan mereka, maka setiap permasalahan dalam kehidupan remaja tidak dapat terjawab oleh pengajaran yang diberikan, serta remaja tidak akan mendapatkan pertumbuhan yang sehat sebagaimana mestinya.

Berdasarkan penjelasan di atas, pelatihan bagi para pendidik untuk menyusun kurikulum PAK remaja dipandang sangat penting. Hal ini dipandang sebagai bagian dari pendidikan agama Kristen kepada masyarakat yang berfokus pada pelatihan penyusunan kurikulum PAK remaja, sehingga kelak para pendidik dapat menyususun kurikulum PAK remaja dengan baik yang sesuai untuk kebutuhan pertumbuhan remaja. Untuk itu, para pendidik perlu mendapatkan pelatihan penyusunan kurikulum PAK remaja yang dirancang secara baik, sistematis, dan disengaja sehingga mereka mendapatkan pengetahuan yang memadai.

Ada beberapa alasan mengapa pelatihan ini dilakukan: Pertama, pemahaman para pendidik remaja mengenai penyusunan kurikulum PAK remaja masih sangat kurang, padahal sebagai seorang pendidik remaja, seharusnya dapat menyusun kurikulum PAK remaja. Kedua, penyusunan kurikulum yang benar sangat penting bagi para pendidik sehingga mereka handal dalam mengatasi setiap permasalahan yang ada di kehidupan remaja sekarang, serta mampu menempatkan diri mereka secara bijaksana. Ketiga, melalui pelatihan ini, para pendidik remaja diharapkan dapat menyusun kurikulum PAK remaja menjadi lebih baik.

Program ini dilaksanakan dengan tahap-tahap sebagai berikut: Pertama, survei kebutuhan pelatihan penyusunan kurikulum PAK remaja dengan mengadakan wawancara tidak terstruktur dengan para pembina dan pendidik kerohanian remaja di HKBP Jatisampurna Bekasi. Kedua, melakukan penyusunan kurikulum PAK remaja. Hal yang dilakukan adalah menyusun kurikulum, materi ajar, peralatan pembelajaran, pengajar, dan sebagainya. Ketiga, melaksanakan pelatihan dengan jadwal yang teratur. Keempat, mengadakan evaluasi yang kemudian akan dijadikan dasar atau rujukan dalam menyelenggarakan program lanjutan.

Tujuan dengan adanya pelatihan ini, bagi para pendidik remaja di HKBP Jatisampurna Bekasi, para pendidik dapat meningkatkan kemampuan dalam 
menyususun kurikulum PAK remaja, meningkatkan pelayanan remaja, dan meningkatkan keterampilan dalam menangani setiap kebutuhan yang diperlukan untuk menunjang pertumbuhan kerohanian remaja.

\section{METODE}

Kegiatan ini dilakukan dengan memberikan pelatihan penyusunan kurikulum PAK remaja kepada seluruh pembina remaja HKBP Jatisampurna Bekasi. Kegiatan dilakukan dengan menggunakan metode ceramah, diskusi, tanya jawab, dan tes. Semua metode tersebut digunakan untuk menjelaskan pengetahuan, panggilan pelayanan remaja, karakteristik pertumbuhan remaja, masalah-masalah perkembangan remaja, baik secara fisik, psikologis, dan kognitif, serta melatih para pendidik remaja bagaimana menyusun kurikulum PAK remaja yang sesuai dengan kebutuhan remaja untuk menjawab masalah-masalah remaja.

\section{HASIL DAN PEMBAHASAN}

Kegiatan ini secara garis besar mencakup beberapa komponen sebagai berikut: ketercapaian target pelatihan yang telah direncanakan, ketercapaian target materi yang telah direncanakan, dan kemampuan peserta dalam pemahaman materi. Peserta yang hadir dalam kegiatan 1016 orang. Dilihat dari kehadiran, diskusi, tanya jawab, pengerjaan tugas-tugas, dan test yang diikuti peserta, mereka sangat antusias untuk mengikuti pelatihan penyusunan kurikulum PAK remaja, sehingga dapat disimpulkan bahwa tujuan kegiatan ini telah tercapai. Ketercapaian target materi pada kegiatan PkM ini sangat baik, karena materi dapat memberikan pemahaman bagi para pendidik remaja, bagaimana cara menyusun kurikulum PAK remaja yang sesuai dengan kebutuhan. Evaluasi dilakukan melalui pemberian tugas atau test yang diberikan di awal pertemuan. Test tersebut memuat pertanyaan dari materi pembelajaran minggu sebelumnya. Hal ini dilakukan untuk mengetahui keberhasilan program PkM yang telah dilaksanakan. Dari hasil test yang diberikan kepada para pembina remaja, ada sebanyak $63 \%$ pembina remaja yang menjawab dengan sangat baik. Sebanyak $25 \%$ pembina remaja menjawab dengan baik, dan sebanyak $12 \%$ pembina remaja yang menjawab dengan cukup baik.

\section{PEMBAHASAN}

Dalam pelatihan ini para pembina remaja mendapat berbagai pengetahuan tentang panggilan pelayanan remaja, karakteristik, dan permasalahan yang sering terjadi pada remaja; perkembangan remaja (perkembangan fisik, kognitif, sosialemosional); kurikulum PAK remaja, dan para pembina juga mendapat pelatihan bagaimana cara menyusun kurikulum PAK remaja yang sesuai dengan kebutuhan remaja. Adapun pokok pembahasannya yaitu:

1. Panggilan Pelayanan Remaja

Gereja terkadang mengabaikan pelayanan bagi kaum remaja, kebanyakan gereja hanya fokus dengan pelayanan kepada orang-orang dewasa, sehingga sering sekali remaja tidak mendapatkan pelayanan yang 
sesuai dengan kebutuhan perkembangannya. Remaja adalah generasi penerus gereja yang akan datang, bila pelayanan remaja tidak ditangani dengan tepat, maka kemungkinan besar ketika dewasa hidup mereka jauh dari kebenaran Firman Tuhan. Dengan demikian, panggilan pelayanan remaja sangatlah penting, karena panggilan tersebut diyakini berasal dari Allah. Efesus 4:12-16 menjelaskan bahwa Tuhan memanggil semua orang percaya untuk diperlengkapi bagi pekerjaan pelayanan-Nya, termasuk dalam memperlengkapi kaum remaja. Remaja yang sehat adalah remaja yang memiliki pemahaman Firman Tuhan yang kuat, mempunyai konsep diri yang positif, dan memiliki suasana emosi yang benar.

\section{Karakteristik dan Permasalahan Remaja}

Persepsi umum mengenai remaja adalah sering dianggap sebagai generasi yang sulit diatur, mau menang sendiri, senang memberontak, malas, tidak bertanggung jawab, tidak punya pendirian, tidak memikirkan hari esok, mudah berkonflik, mudah tersinggung, dan lainnya. Persepsi ini membuat remaja merasa dirinya sering disepelekan, merasa mendapatkan perlakuan diskriminatif dari orang-orang dewasa, dan merasa terabaikan. Untuk itu, pembina remaja membutuhkan kompetensi khusus, salah satunya harus mengetahui dengan baik mengenai karakteristik dan permasalahan remaja.

Beberapa karakteristik remaja dapat digambarkan: senang mencoba hal-hal yang baru (yang belum diketahuinya), suka membuat kelompok dengan teman-teman sebayanya, suka mengkhayal, ingin melepaskan diri dari orangtua (mandiri) padahal mereka belum mampu, dan gelisah karena mereka mempunyai banyak anganangan yang hendak diwujudkan di masa depan, namun kemampuan mereka belum mampu untuk mencapai hal-hal tersebut (Ali, 2010, 16-18). Karakteristik remaja terbentuk dari dua faktor yaitu: faktor dari dalam dirinya (internal) dan faktor dari luar (eksternal). Terbentuknya kenakalan remaja bisa disebabkan oleh faktor internal, yaitu karena krisis identitas dan kontrol diri yang lemah, sedangkan faktor eksternal dapat disebabkan oleh kondisi keluarga yang tidak harmonis, kurangnya perhatian dan kasih sayang dari orangtua, penerapan disiplin/pola asuh orangtua yang tidak tepat, status sosial ekonomi orangtua yang rendah, pengaruh buruk dari lingkungan sekitar, teman sebaya, teknologi, pendidikan yang kurang bermutu dan karena minimnya pemahaman tentang keagamaan yang membekali remaja dengan pondasi Firman Tuhan (Sumara, 2017, 129389).

Berdasarkan penjelasan di atas, dapat dilihat bahwa sangat penting sekali peran orangtua dan pembina remaja dalam membentuk karakteristik remaja. Adapun posisi orangtua dan pembina dalam mendidik remaja antara lain: Pertama, menjadi pembimbing (edukator). Di mana orangtua dan pembina remaja harus dapat memberikan bimbingan yang tepat dan sesuai dengan kebutuhan remaja dalam menjawab setiap permasalah dalam pertumbuhan dan 
perkembangan remaja. Kedua, menjadi pendamping (konselor). Orangtua dan pembina remaja harus dapat mendampingi remaja dalam tiga aspek, yaitu memperhatikan perkembangan kognitif, afektif, dan psikomotorik remaja. Ketiga, menjadi motivator. Dalam hal ini, orangtua dan pendidik harus memberikan support dan motivasi dengan sikap empati kepada remaja dalam memberikan penguatan di saat remaja merasakan kegelisahan di dalam dirinya (Ismail, 2004, 147). Dengan demikian, apabila tugas-tugas tersebut dapat dilakukan dengan baik tentunya remaja yang dididik akan memiliki pertumbuhan yang sehat.

\section{Psikologi Remaja}

Pembahasan ini membahas mengenai perkembangan fisik, kognitif, emosional, dan spritual pada remaja. Pertama, masa perkembangan fisik remaja antara lain, perubahan hormonal, pertambahan tinggi, dan berat badan, kematangan organ reproduksi, dan lainnya. Permasalahan yang sering terjadi pada kaum remaja akibat dari perkembangan fisik, biasanya terjadi karena keadaan fisik yang tidak sesuai dengan harapannya, dan juga masalah kematangan organ reproduksi yang membutuhkan upaya pemuasan, sehingga remaja sering terjerumus pada penyimpangan dan prilaku seksual (Ahyani \& Astuti, 2018, 93). Kedua, masa perkembangan sosialemosional/psikologis remaja ciri-cirinya antara lain: memiliki energi yang besar, emosi berkobar-kobar di mana pengendalian diri belum sempurna, sering mengalami perasaan tidak aman, tidak tenang, dan kuatir kesepian, masa stress emosional yang timbul karena perubahan fisik, ingin bergaul dan diterima oleh lingkungan, dan remaja cenderung menggunakan cara modelling terhadap orangorang yang diidolakan (Ahyani \& Astuti, 2018, 93). Ketiga, masa perkembangan kognitif di mana remaja mengalami kekuatan peningkatan berpikir seperti, pemikiran semakin abstrak, logis, dan idealis, lebih mampu menguji pemikiran diri sendiri, pemikiran orang lain, dan apa yang dipikirkan orang lain tentang mereka, kemampuan untuk mengembangkan hipotesis, memecahkan masalah, menarik kesimpulan, atau menyimpulkan pola mana yang cocok dalam memecahkan masalah. Dalam perkembangan kognitif permasalahan yang sering terjadi pada remaja, yaitu tidak mendapatkan kesempatan untuk mengembangkan kemampuan kognitifnya. Hal tersebut tentunya sedikit banyak akan menghambat kesuksesan hidup dan karirnya (Ahyani \& Astuti, 2018, 93). Keempat, masa perkembangan spritual remaja. Spiritual pada remaja sangat dipengaruhi oleh peran orangtua dan pembina yang merupakan model yang ditiru perilakunya di dalam kehidupan setiap hari. Jika dalam lingkungannya remaja tidak mendapat dukungan, maka tingkat spiritualnya akan menjadi rendah. Menurut Biddle dan Gorely sebagaimana dikutip oleh Retno M. Rahmat A, remaja yang memiliki hubungan yang positif dengan orangtuanya akan berdampak pada pola perilaku yang baik. Simon dan Conger juga berpendapat bahwa gaya 
pengasuhan yang konsisten dari orangtua dapat memberikan hubungan yang positif bagi perkembangan spiritual remaja. Selain itu, ajaran agama yang diberikan di gereja oleh para pembina remaja juga merupakan faktor penting dalam mempengaruhi perkembangan spiritual remaja. Agama adalah sistem organisasi kepercayaan dan peribadatan di mana seseorang dapat mengungkapkan secara jelas spiritualnya (Rahmat A, 2017, 32). Dengan demikian, selain orangtua para pembina remaja sangat memiliki peran yang penting dalam pembentukan karakter spritual remaja dalam pertumbuhannya.

Sebagai orangtua, pembina remaja tentunya harus mengetahui dan memahami perkembangan psikologi remaja. Jika remaja sudah memiliki pemahaman yang baik tentang psikologi perkembangan remaja tentunya akan mempermudah pendidik dalam mendidik anak didiknya. Setiap peserta didik memiliki masalah yang berbeda-beda, tetapi dengan adanya pengetahuan dan pemahaman mengenai psikologi remaja yang baik, para pendidik akan dapat menentukan solusi yang tepat dalam setiap permasalahan yang dihadapi oleh kaum remaja.

\section{Kurikulum PAK Remaja}

Unsur-unsur dalam perkembangan kurikulum adalah tujuan, isi atau materi pelajaraan metode atau strategi, dan evaluasi. Adapun empat asas dalam penyusunan kurikulum PAK remaja yang harus diketahui para pembina remaja: Pertama, asas filosofis, pembina harus mengajarkan kebenaran Injil Allah dan hubungan antara manusia dengan
Allah. Kedua, asas psikologis, pembina harus memperhatikan perkembangan remaja. Ketiga, aspek sosiologi, pembina harus memperhatikan nilai-nilai budaya dan adat istiadat yang akan membentuk kepribadian remaja. Keempat, asas organisatoris, pembina harus memperhatikan bentuk dan bahan pembelajaran yang akan disajikan.

Setiap remaja memiliki kebutuhan yang berbeda-beda. Dalam pelatihan penyusunan kurikulum PAK remaja di HKBP Jatisampurna, pembina remaja harus melakukan analisis kebutuhan agar dapat mengetahui kebutuhan remaja. Setelah para pembina menganalisis setiap permasalah remaja tersebut, para pembina sudah dapat membuat kurikulum remaja yang sesuai dengan kebutuhan mereka, dalam menjawab setiap permasalah-permasalah yang ada di kalangan remaja yang mereka didik.

Dalam sesi diskusi ada beberapa pertanyaan yang diajukan oleh para pembina remaja yang diringkas menjadi pokok-pokok diskusi, yaitu:

1. Kondisi Ekonomi Keluarga Menjadi Pemicu Kenakalan Remaja

Ekonomi keluarga dapat
mempengaruhi kenakalan pada anak remaja bila kondisi ekonomi keluarga sangat rendah sementara remaja berkeinginan besar untuk memenuhi harapan-harapannya. Contohnya, keluarga yang tidak mampu membiayai anaknya sekolah dan pada akhirnya anak tersebut putus sekolah dan menjadi stress dan malu terhadap teman-temannya, dapat membuat anak melampiaskannya dalam 
bentuk kenakalan. Selain itu, gaya hidup temannya yang memiliki ekonomi keluarga yang mapan dapat membuat anak menjadi minder dalam pergaulannya. Anak dapat melawan orangtuanya jika keinginannya tidak dipenuhi. Untuk mencegah hal tersebut, orangtua harus seoptimal mungkin bekerja untuk meningkatkan ekonomi keluarga. Akan tetapi bukan berarti setiap keinginan anak harus dituruti atau dipenuhi. Anak harus diajar sedini mungkin untuk belajar bersyukur untuk kehidupan keluarganya, dan diajar untuk terlibat dalam mengatasi masalah ekonomi keluarga melalui pemikiran, kesungguhan belajar, meminta pertolongan kepada Tuhan, dan kreativitas berwirausaha yang dilakukan secara sukarela dan sesuai kemampuannya.

2. Cara Menetapkan Prioritas dalam Pelayanan Remaja

Pembina remaja dapat menetapkan prioritas dalam pelayanan remaja bila Pembina sudah melakukan analisis kebutuhan remaja. Hal ini dilakukan untuk mengetahui masalah dan kebutuhan remaja. Pembina remaja juga dapat meminta masukan dari remaja, para orangtua, para pemerhati remaja di gereja, pemimpin di gereja, psikolog, dan lain-lain.

\section{Perlunya Visi dan Evaluasi dalam Pembinaan Remaja \\ Pembinaan remaja sebagai suatu} pendidikan haruslah dipersiapkan sebaik mungkin. Karena itu, visi mutlak diperlukan untuk menentukan arah pembinaan remaja dan capaian yang harus dipenuhi. Demikian pula evaluasi sangat diperlukan untuk mengukur keberhasilan pembinaan atau pendidikan yang dijalankan, atau untuk mengukur ketercapaian visi.

4. Keharusan untuk Mengetahui Rahasia Remaja

Tidak semua rahasia remaja harus diketahui oleh pembina remaja atau oleh orangtua. Yang terpenting adalah pembina atau orangtua dapat mengetahui permasalahan apa yang menghambat pertumbuhan mereka dan apa yang menyebabkan mereka melakukan kenakalan.

\section{Cara Melakukan Penyembuhan Luka Batin terhadap Orangtuanya \\ Banyak cara yang dapat dilakukan} untuk memulihkan luka batin yang ada pada diri remaja, misalnya membuat hubungan yang dekat atau persahabatan dengan remaja sehingga membuat mereka terbuka akan masalahnya. Hal ini membuka kesempatan untuk membantu menyembuhkan luka batinnya dengan mencari solusi, menguatkan dengan mendoakannya, menjadi mediator rekonsiliasi remaja dengan orangtuanya, dan mengadakan ibadah penguatan. Pembina remaja juga dapat mengadakan seminar yang mengundang para orangtua yang berfokus pada pemulihan hubungan remaja dengan orangtua.

6. Cara Mengupayakan Kedisiplinan dalam Pembinaan Remaja

Kedisiplinan di dalam pelayanan remaja harus diterapkan oleh gereja dan para pendidik, dan perlu juga mengevaluasi sejauh mana keberhasilan pelayanan yang telah 
dilakukan. Dengan begitu pelayanan remaja akan terlaksana dengan maksimal. Salah satu kedisiplinan yang dapat dilakukan, yaitu membuat evaluasi paling tidak sekali dalam setahun untuk mengetahui sejauhmana keberhasilan pelayanan remaja yang telah terlaksana.

7. Pembina harus memperhatikan kognitif, afektif, dan psikomotorik remaja

Pembina remaja harus memperhatikan kognitif remaja untuk melihat sejauh mana pemahaman dan pengetahuan Alkitab atau ajaran Kristen yang telah didapat remaja. Pembina juga harus memperhatikan aspek afektif di mana remaja mampu merespon setiap pengajaran yang telah diberikan kepadanya yang tampak melalui sikap hati. Aspek psikomotoriknya harus diperhatikan untuk melihat apakah remaja sudah menerapkan atau mempraktikkan pengajaran di dalam kehidupannya.

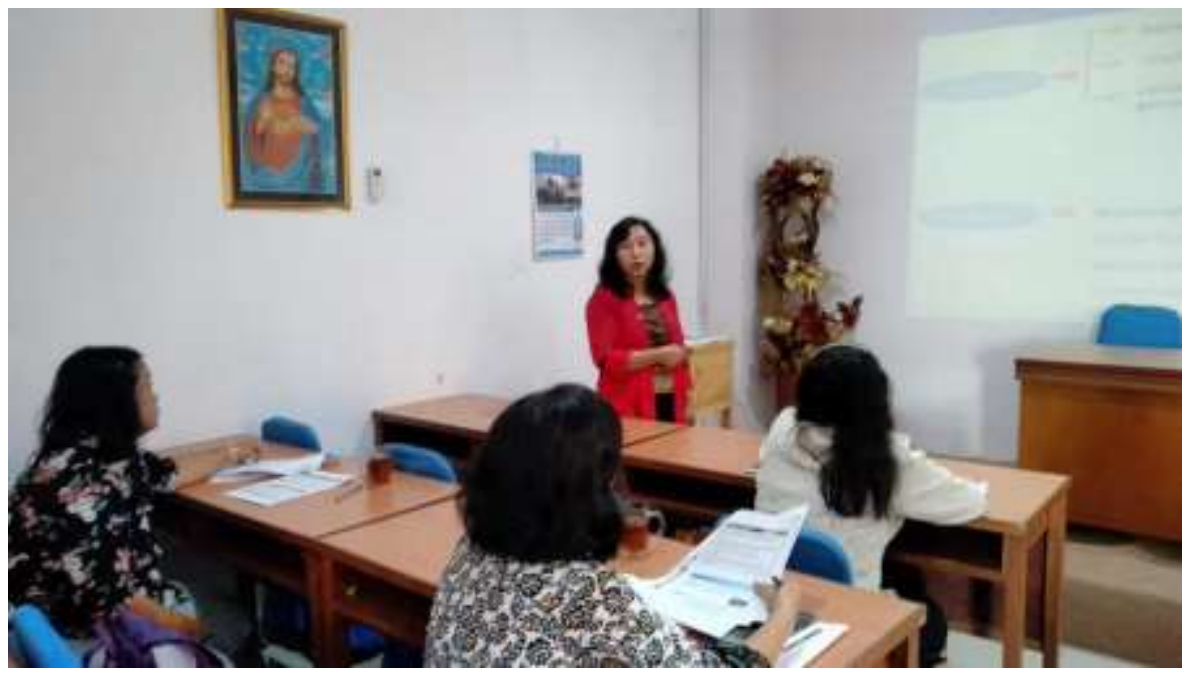

Gambar 1.

Dr. Desi Sianipar, M.Th. (Ketua TIM PkM) sedang memberikan materi dan pelatihan bagi para pembina remaja di HKBP Jatisampurna Bekasi
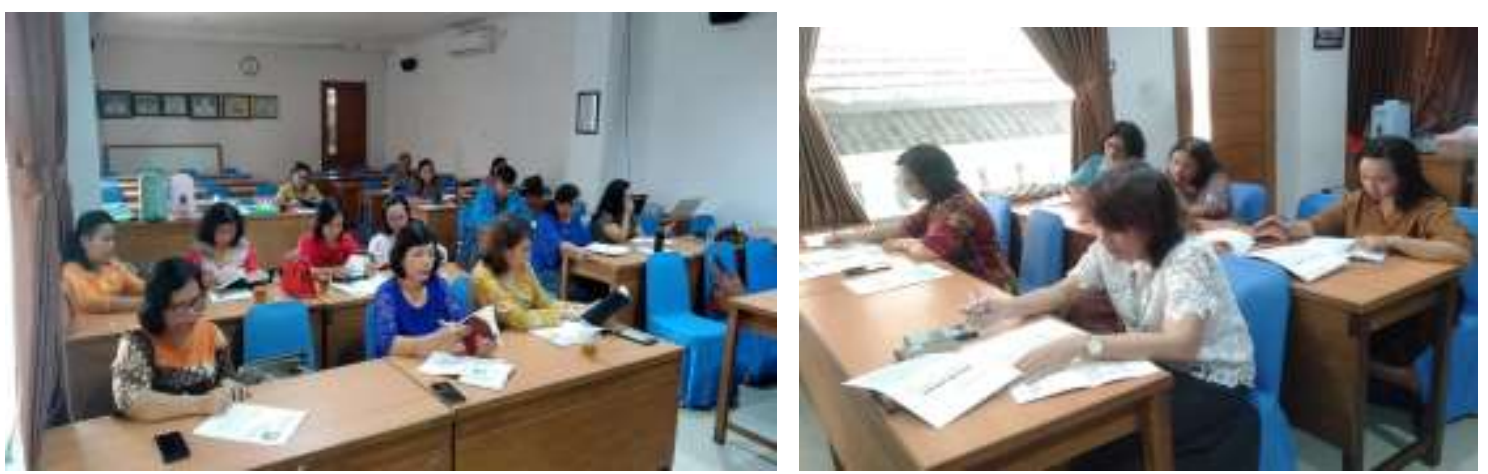

Gambar 2.

Para pembina remaja yang sedang mengikuti pelatihan penyususan kurikulum pendidikan agama Kristen remaja di HKBP Jatisampurna Bekasi 


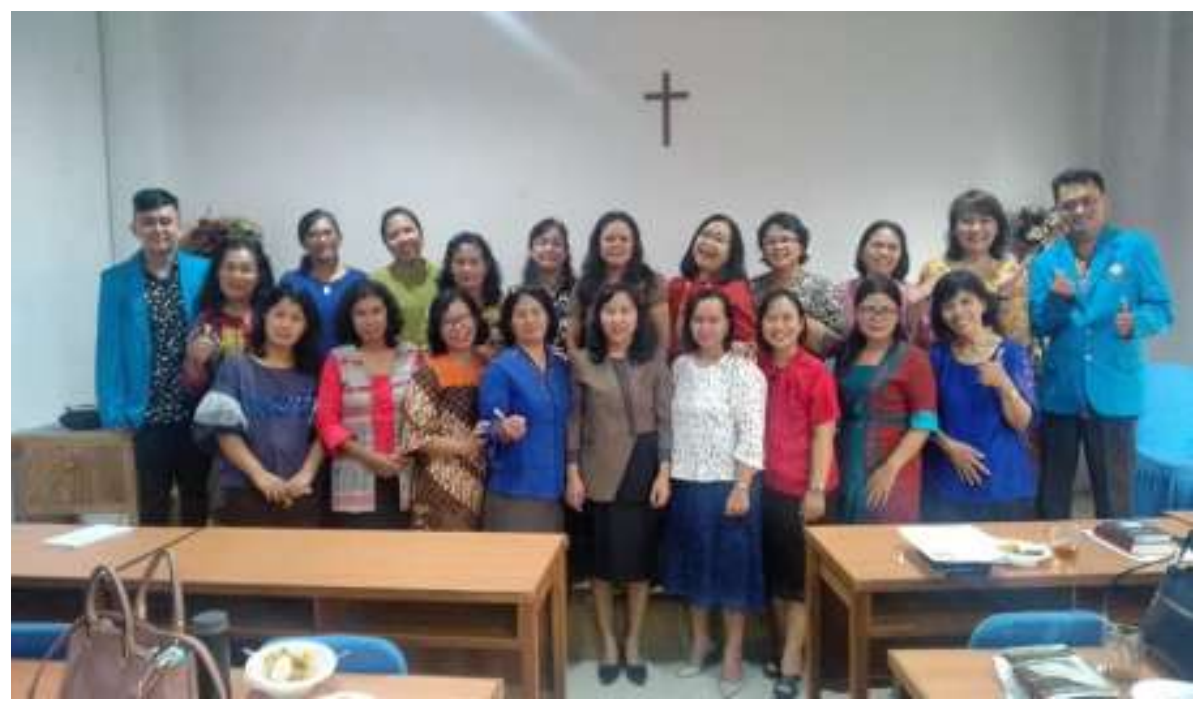

Gambar 3.

Dosen dan Mahasiswa PkM bersama para pembina remaja di HKBP Jatisampurna Bekasi, setelah mengikuti kegiatan pelatihan.

\section{SIMPULAN}

Program pelatihan kurikulum ini telah dilakukan sebagai bagian dari pengabdian kepada masyarakat yang dilakukan oleh dosen dan mahasiswa, berdasarkan kebutuhan para pembina remaja HKBP Jatisampurna. Kegiatan dilakukan selama tiga minggu pada bulan Maret 2020. Hasil yang diharapkan dari kegiatan ini adalah para pembina remaja dapat memahami panggilannya dengan baik dan memahami perkembangan remaja dari tiga aspek, yakni fisik, psikologis, dan kognitif. Selanjutnya, mereka diharapkan dapat menyusun kurikulum yang sesuai dengan kebutuhan remaja dan teologi yang dianut gereja. Kegiatan ini telah mendapat sambutan yang sangat baik dari pimpinan gereja dan para pembina remaja HKBP Jatisampurna yang terlihat dari antusiasme mereka dalam mengikuti pelatihan ini. Mereka juga berharap UKI dapat memberikan pelatihan lanjutan.

\section{UCAPAN TERIMAKASIH}

Dengan terselenggaranya kegiatan pengabdian kepada masyarakat dengan baik dan lancar, maka kami mengucapkan terima kasih yang sebesar-besarnya kepada:

Pimpinan Universitas Kristen Indonesia yang telah memfasilitasi dengan dana untuk pelaksanaan pengabdian kepada masyarakat sehingga dapat terlaksana dengan baik.

Pimpinan Lembaga Penelitian dan Pengabdian kepada Masyarakat UKI (LPPM) yang telah memproses mulai dari pengajuan proposal PkM hingga Tim dapat menyelesaikan PkM dan menyusun Laporan PkM, serta membantu publikasi hasil PkM dalam jurnal PkM LPPM UKI.

Direktur Program Pascasarjana yang telah menugaskan dosen dan mahasiswa Prodi Magister Pendidikan Agama Kristen dalam melaksanakan PkM ini.

Pimpinan atau Gembala Sidang di HKBP Jatisampurna Bekasi yang telah bermitra dengan UKI sehingga memberikan 
Volume 2, Nomor 2, Tahun 2020 Hal 447 - 457

kesempatan kepada Tim PkM melaksanakan kegiatan PkM ini.

\section{DAFTAR PUSTAKA}

Ali, Mohammad (2010). Psikologi Remaja Perkembangan Peserta Didik. Jakarta: Bumi Aksara.

Budiyana, Hardi (2011). Dasar-Dasar Pendidikan Agama Kristen. Karanganyar: Berita Hidup Seminary.

Dadan Sumara, Sahadi Humaedi, Meilanny Budiarti Santoso (2017). Kenakalan Remaja dan Penanganannya. Jurnal Penelitian dan PPM, Vol.4 No.2.

Nadeak, B., Sormin, E., Naibaho, L., \& Deliviana, E. (2020). Sexuality in Education Begins in The Home (Pendidikan Seksual Berawal Dalam Keluarga). Jurnal

Comunita Servizio, 2(1), 254-264.

Ismail, Andar (2004). Ajar Mereka Melakukan. Jakarta: BPK Gunung Mulia.

Sianipar, D., Rini, W. A., \& Jura, D. (2019). Peningkatan Pemahaman tentang Komitmen Melayani Karyawan Gerejagereja Kristen Jawa (GKJ) Klasis Jakarta Bagian Timur. JURNAL Comunit $\tilde{A}$ Servizio: Jurnal Terkait Kegiatan Pengabdian kepada Masyarakat, terkhusus bidang Teknologi, Kewirausahaan dan Sosial Kemasyarakatan, 1(1), 50-61.

Rahmat A, Retno M (2017). Pengembangan Spiritualitas Remaja: Mengapa Remaja Laki-laki Lebih Memerlukan Dukungan Keluarga dalam Pengembangan Spiritualitas. Jurnal Psikoislamika, Vol.14 No.1.
Latifah Nur Ahyani dan Rr. Dwi Astuti (2018). Buku Ajar Perkembangan Psikologi Anak dan Remaja Kudus: Universitas Muria Kudus.

Lebar, Lois (2006). E. Education That Is Christian: Proses Belajar Mengajar Kristiani \& Kurikulum yang Alkitabiah. Jawa Timur: Gandum Mas.

LPPM UKI (2018). Pedoman Pelaksanaan Pengabdian Kepada Masyarakat (PkM) Universitas Kristen Indonesia. Jakarta: Lembaga Penelitian dan Pengabdian kepada Masyarakat UKI.

Sianipar, D., Kia, A. D., Rantung, D. A., \& Sairwona, W. (2019). PeningkatanKecerdasanSpiritual Warga Binaan Kristen Melalui Pendidikan Agama Kristen di Lembaga Pemasyarakatan Kelas IIA Salemba Jakarta Pusat. JURNAL ComunitÃ Servizio: Jurnal Terkait Kegiatan Pengabdian kepada Masyarakat, terkhusus bidang Teknologi, Kewirausahaan dan Sosial Kemasyarakatan, 1(2), 89-97. 